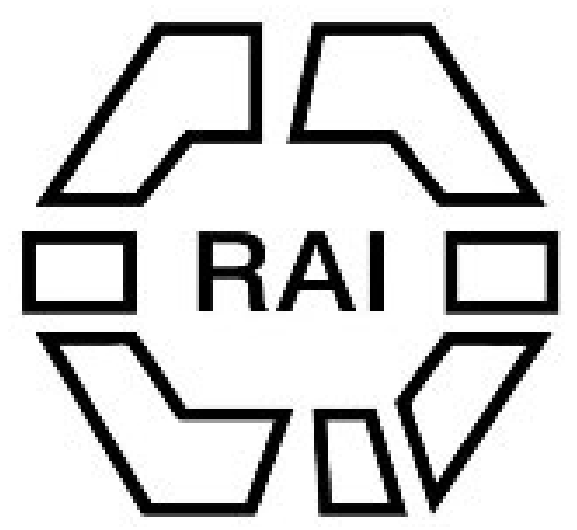

The Original Range of the Papuan and Negritto Races.

Author(s): Francis A. Allen

Source: The Journal of the Anthropological Institute of Great Britain and Ireland, Vol. 8 (1879), pp. 38-50

Published by: Royal Anthropological Institute of Great Britain and Ireland

Stable URL: http://www.jstor.org/stable/2841189

Accessed: 14/06/2014 06:35

Your use of the JSTOR archive indicates your acceptance of the Terms \& Conditions of Use, available at http://www.jstor.org/page/info/about/policies/terms.jsp

JSTOR is a not-for-profit service that helps scholars, researchers, and students discover, use, and build upon a wide range of content in a trusted digital archive. We use information technology and tools to increase productivity and facilitate new forms of scholarship. For more information about JSTOR, please contact support@jstor.org. 
MARCH $26 \mathrm{TH}, 1878$.

John Evans, Esq., D.C.L., F.R.S., President, in the Chair.

The minutes of the previous meeting were read and confirmed.

The following presents were announced, and thanks were ordered to be returned to the respective donors for the same:-

\section{For THE LIBRARY.}

From the Coloniat Office.-Colonial Office List for 1878.

From the AUTHOR.-Lectures on the Science of Language; 2 vols., 9th Edition. By Prof. Max Muller, Hon. M.A.I.

From Prof. F. V. HAYDen, Hon. M.A.I.-Bulletin of the United

States Geological and Geographical Survey of the Territories.

From the Association.-Report of the Geologists' Association for 1877.

From the Association.-Transactions of the Social Science Association for 1877.

From the EDrToR.- Nature (to date).

From the EDIToR.-Revue Scientifique. Nos. 37 and 38, 1878.

From the EDrror.-Revue Internationale des Sciences. Nos. 11 and $12,1878$.

From the Author.-The Future Australian Race. By Marcus Clarke.

A Paper was read by Francis A. Allen, Esq., on " The Original Range of the Papuan and Negritto Races."

\section{The Original Range of the Papuan and Negritto Races, by Francis A. Allen, Esq.}

AMONGST the numerous and interesting questions which yet remain unsolved in connection with ethnology and anthropology, few, I venture to think, exceed in interest and importance the question of the origin, affinities, and original habitat of the Papuan and Negritto races.*

These Papuans and Negrittos (sometimes called Oriental Negroes or the Oceanic black race) undoubtedly present a very great difficulty to the man of science, and so little is even now known of their languages, customs, and traditions that it seems impossible to form any very confident opinion regarding them.

* I couple these races together as the subject of my paper because they are both located in the same area or at any rute overlap and intersect each other, and are thought by many writers to be cognate. 
Nevertheless, it is highly important that something should be attempted, since, by reason of their unsocial habits, and of the encroachment and persecution to which they have been subjected by the white and brown races, they bid fair at no very distant date to vanish entirely from the muster-roll of nations.

In Tasmania the aborigines are already extinct; in Australia they are rapidly fading away; in Fiji even, where they appeared to be most flourishing and powerful, diseases lately introduced by Europeans bid fair to make a speedy end of them; whilst, throughout all the East India Islands, the brown races have either extirpated them or driven them into the inaccessible fastnesses of the interior.

My desire, to-night, is not so much to describe the Papuans and Negrittos as they at present exist or have existed in Papua, Melanesia, Australia, Tasmania, Ceram, the Philippines, Sulu Islands, Borneo, the Sunda Chain, and in the Andamans, as to point out a few facts which lead me to suppose that these races once occupied a very much wider area than they do at present, being closely connected at a remote epoch with the black races of Africa on the west, and even reaching as far as America on the east; besides forming, very possibly, the aboriginal population of, at any rate, Southern Asia.

Considerable difference of opinion exists, I need hardly remark, as to what the Negrittos or Oceanic Blacks are, and as to how they should be divided. Crawford supposes that there is but one race of Oriental Negroes north of the equator, and two races in the Malay Archipelago and New Guinea. Latham doubts their existence at all on the smaller islands. The more general conclusion, however, seems to be that there is but one race of Oriental Negroes, and that the Australians and Tasmanians must be connected with it. Then again the origin of the Papuans is disputed. Some regard the Negrittos as merely a variety of the Papuans, debased and stunted by hard usage; others regard the superiority of the Papuans as being due to an admixture of Malay blood.

Mr. Wallace,* a very high authority, and, I believe, Mr. Crawford, incline to maintain that the Papuans are the aborigines of a former Polynesian Continent, and stamp the brown race as the hybrid - the black race being, in their opinion, the abori ginal one.

H. C. von der Gabelentz, after a careful investigation of the Melanesian dialects, concludes that all the Melanesian languages, though disintegrated and apparently separated from one another, owing to the barbarisn and isolation of the

* See Wallace's "Malay Archipelago," Chap. XV. 
tribes, do yet belong to one stock. $\mathrm{He}$ is also of opinion that, both in the roots and in many grammatical peculiarities, there are numerous remarkable resemblances between the Polynesian and Melanesian languages, so that the hypothesis of their common origin he regards as a highly probable one.*

It seems reasonable to regard both the black and brown races as successive off-shoots from the Turanian stock; but the position of the black race in the interior of the islands and its constant persecution by the brown race prove, I think, very clearly its superior antiquity. Possibly, also, the Negrittos may have preceded the Papuans themselves in their islands.

I must not omit to allude here to the Fijian race, which increases the general confusion, being apparently composed of conflicting elements, and having a language said to be one-fifth Polynesian, and four-fifths unlike any other neighbouring tongue. Nevertheless its manners, customs, and habits prove it, I think, to be mainly Papuan. Without dwelling further upon these elements of difficulty in treating the subject, I will proceed to call your attention to the external resemblance which has been so often remarked between two widely separated races, i.e., the African and Oceanic black races popularly called Negro and Negroid respectively.

I do so because Professor H. G. Seeley has recently revived a hypothesis which I think unnecessary and misleading regarding them. Fully agreeing as I do with the learned Professor that the resemblances between the two races are too numerous and remarkable to admit of any other interpretation than that of a common origin at some remote epoch, I do not feel disposed to coincide in the theory by which he attempts to account for their present separation. He said in the first of his lectures upon Evolution, delivered lately in London, $\dagger$ that "though the Negro is now almost confined to Africa, and is not migratory, yet formerly a ridge of land ran viâa Madagascar, the Seychelles, and across to Borneo, and hence there was a path for the mixture of races. The submergence of the ridge, leaving now only the tops of hills above the water, had isolated the Negro and Malay again."

Now, assuming the above to be a tolerably accurate outline of the bent of his argument and without disputing the geological accuracy of the statement, it appears to me both unwise and superfluous to imagine any communication between the races of Africa and Polynesia by this route when good evidence exists

* From his " Die Melan Spr." Leipzig, 1860, quoted in Brace's " Races of the Old World, "Murray, 1863.

$\uparrow$ Delivered at the College for Men and Wornen, Bloomsbury, on Friday, October 19th, 1877 and reported in The Times, October 26th, 1877. 
that communication has been equally possible since the contiments assumed their present shape. Let me try to trace the links between Africa and Oceania. A dark Negritto race exists, we know, at the present day, in the Andaman Islands, and perhaps in the interior of the Nicobars, close to the mainland of Asia. Other black races exist still in the Indo-Chinese Peninsula. Excluding the disputed case of the wild Semangs,* who inhabit the mountain fastnesses of the Malayan Peninsula near Malacca, and whom some claim as a wild brown tribe (perhaps the original stock of the Malays), there are the Moys on the mountains between Cochin China and Laos, and Cambodia. It is a pity that no modern traveller appears to have visited them. They were undoubtedly the aborigines of Cochin China and were only driven into the mountains by the Kings of Tonquin in the 15th century. They are said to be woolly-haired, very black and savage, and with faces resembling Kaffirs (of Africa ?). $\dagger$ Mr. Earl, in his well-known work on 'The Papuans, says that the first European traveller who fixed on them a Papuan character was Mr. Charles Chapman, who was an officer in the East India Company's service sent to Cochin China on a mission in 1778. He reported thus of them to his Government :"The Aborigines of Cochin China are called Moys, and are the people which inhabit the chain of mountains which separate it from Cambodia. To these strongholds they were driven when the present possessors invaded the country. They are a savage race of people, very black, and resemble in their features the Caffrees."

A tribe called "Mai," which may be the same people, is also mentioned in an Essay on the Indo-Chinese countries in Moor's Notices of the Indian Archipelago, and which has been attributed to Mr. Craufurd, the historian of the Indian Archipelago, in the following terms :-

"The most numerous inhabitants of this province are the proper Kambodians. The Anam race are the masters. The original inhabitants of that portion of it lying to the eastward of the great river and bordering on Lao, are a tribe called Mai." $\ddagger$

Mr. Earl adds :- " I have entered into this subject more fully than I should otherwise have done, with a view of suggesting to those interested in the archæological branch of ethnography, the importance of the results that may attend a closer inquiry into the characteristics of this primitive race. It is well known that

* I have no doubt myself of the Papuan origin of this race. See descriptions in Earl's "Papuans" chap. IX ; Science Gossip for 1866, Hardwicke and Bogue, pp. 239-261, \&c.

† See Tomlin's “Geography,” p. 510, London, 1841, and Earl's “ Papuans," pp. 158-60.

† P. 192. 
many of the ancient idols of the Hindus have Negro characteristics, and the great Budha himself, who is also sometimes represented as a negro, is said by his worshippers to have been born of a female named 'Maia.' The traditions of the Chinese respecting the earlier inhabitants of their country, and the high veneration in which even those who are untainted with Budhism hold the Waringin, the Banyan-tree of the Far East, are also interesting subjects of inquiry."

On p. 116 of his work he explains his latter allusion to refer to the wilder Papuans delighting to dwell high up among the branches of this tree, and to the superstitious reverence with which all the aboriginal tribes of the Archipelago, as well as those of the northern coasts of Australia, and the lower classes, at least, of the Chinese regard it. The Papuan custom of making a home in trees or upon elevated platforms still prevails in Cambodia, I observe from perusing the accounts of recent travels in that country.*

The Papuan and Negritto races are not at present traceable in India, although they are mentioned in the sacred books of the Hindus as living far to the south-east. $†$ Some of the ancient geographers, however, mention cannibal dwarfs (Negrittos?), as dwelling on the Ganges in their time.

Dr. Pritchard cites two instances in which a strong resemblance to negro peculiarities came under his notice in Indiaone amongst the Brinjarry tribe-and in connection with this fact refers to the reported existence of a tribe of blacks in the vicinity of Lake Zurrah in Central Persia, and also to the description by Herodotus of the Asiatic Ethiopians. $\neq$ It was his opinion, "that the Negritto race once occupied more space than it does at this time, and that in many cases it has preceded the dissemination of other races," (p. 180).

They certainly appear to have played a more prominent part in the East in bygone times than they do now, for Mahometan travellers, $\$$ in the age immediately succeeding Mahomet, speak of the Andaman Islanders as cannibals infesting the Straits of Malacca, and as having been expelled to their present home by force; while Valentyn, an old Dutch historian of the East, describes the Papuans of Ceram, in the early part of the last century, as being cannibals, and organising extensive fleets to plunder the adjoining coasts.\| It is needless to say that in the present day no Papuan or Negritto tribe (except perhaps in Papua) is aggressive.

* See Mouhot's "Cambodia," p. 238.

+ See Pickering's "Races of Men," p. 174.

I Ibid., pp. 145-6.

§ See translation by Eusebius Renaudot, Earl's " Papuans," p. 169.

II Earl's "Papuans," pp. 114-5. 
Ferguson, in his History of Architecture, calls attention to the curious fact that opposite to the cave-temples of Western India, we find the troglodytes of Eastern Africa. He inclines, however, to consider this an accidental coincidence arising from geological causes.

The presence of black races (nearly identical with the Negro races of Africa) in Western Asia and almost in close proximity to the African Continent, within the historical period, is, if it can be duly substantiated, a most interesting and suggestive fact.

All classical students know that the ancients uniformly divided the Ethiopians (whose very name aitio $\psi$, black, indicated their colour) into the Eastern and Western Ethiopians, and that this distinction was kept up until very recent times. It has been frequently supposed that this arose from a mere confusion in the ideas of the old geographers and from scanty information; but it is difficult to understand how so exact an authority as Herodotus could be so grossly deceived as to races existing near to him, and the more so as his own travels were apparently very extensive.

Most of the races of mankind were evidently well known to him, and if he had heard of the Akkha dwarfs of Schweinfurth and of the Samoyedes of Siberia, is it likely he did not know the difference between the Eastern and Western Ethiopians when he spoke of them ?* It is to be observed that they cannot be the Arabs, Indians, or Egyptians, for he carefully distinguishes the Ethiopians from these. Yet he speaks of Ethiopians serving with the Indians in the Persian armies, and appears to consider them the aboriginal population of a part of Western Asia. The true view to take of all this evidence appears to me to be to assume that Herodotus was correct. Why should we not believe that there were two races of Ethiopians, just as there were two Cushes, two Arabias, and two Ethiopias, $\uparrow^{\dagger}$ and that in his time, a Negroid race of Asiatics, totally distinct from the Negro Africans, was dwelling in Mesopotamia or thereabouts?

* The Ethiopians from the Sun-rise (for two kinds served in the expedition) were marshalled with the Indians, and did not at all differ from the others in appearance, but only in their language and their hair. For the Eastern Ethiopians are straight-haired; but those of Libya have hair more curly than that of any other people. These Ethiopians from Asia were accounted almost the same as the Indians; but they wore on their heads skins of horses' heads, as masks, stripped off with the ears and mane; and the mane served instead of a crest, and the horses' ears were fixed erect; and as defensive armour they used the skins of cranes instead of shields." (Polymnia, Book III. Section 70. Cary's translation.)

† See Genesis ii. 13, where a river running from Eden is said to encompass the whole land of Ethiopia or Cush. 
It is to be observed that Herodotus says that the difference between the two races consisted in the language and the hair. Now one great difference between the Papuans and African negroes consists also in the hair, for while both have frizzled or woolly hair, the hair of the Papuans does not spread over the surface of the head like that of the African negroes, but grows in small tufts or knobs, each of which keeps separate from the rest, and the hairs, if allowed to grow, twist round each other, and form spiral ringlets.* This produces much the same effect as is observable in the hair represented on the Assyrian sculptures, and a very close approximation to the same peculiarity is to be seen on some of the figures sculptured upon the walls of Palenque in Central America. Herrera (quoted by Stephens in his work, p. 533,) says that the Indians of Yucatan (Mayas ?) wore their hair in tresses of spiral curls at the time of the Conquest. May this not suggest that the Papuan race was more closely connected with the early civilized Turanian races than we usually imagine? But Herodotus seems to say that the Asiatic Ethiopians had smooth hair. If this was the case, it merely indicated a very slight admixture of foreign blood, for Mr. Earl tells us (p. 3) that " a comparatively slight mixture with the brown race removes the peculiarity, at least has done so in all cases that have come under the writer's observation. The hair of people of the mixed race, although thick and curly, covers the surface like that of Europeans." This fact may explain how it is that the prevailing character of the hair amongst the aborigines of Australia is straight or only slightly waved, and often fine and silky, (even at Cape York) although frizzled hair is also very prevalent on the north and north-east coasts. $\dagger$ Dr. Pickering also noticed that the hair was straight amongst the Brinjarry tribe in Western Hindostan whom he had suspected (from the Negroid features of some individuals) of inheriting Papuan blood.+

Another interesting fact tending to prove the existence of aboriginal black races in Western Asia, is the legend of the Asiatic Memnon. This legendary chieftain is spoken of by Homer in the Iliad as an Ethiopian King, a son of Aurora, who came to the assistance of the Trojans, and during the war was killed by Achilles, who wished to avenge the death of Antilochus. This prince has been too readily assumed to be an African because he was an Ethiopian, but Homer nowhere says that he came from Africa, and the conjecture is in itself wildly improbable. The classical writers of antiquity first led to his

* See Earl's “Papuans," pp. 1-2.

† Earl's "Papuans," p. 189.

$\$$ Pickering's " Races of Men," p. 146. 
being referred to Africa, by connecting him with the Memnon of Thebes and the mysterious musical statue of that ilk. But this name can be distinctly traced to a stupid Roman blunder of the time of Adrian, which transformed an Egyptian statue of Amenoph III of the 18th Dynasty, and the tombs of Amenoph and Mëiamoun, into the statue of Memnon and the Memnonium by a whimsical play upon words or rather sounds.*

Surely, if his being the son of Aurora means anything, Memnon must be derived from the East and not from the South! Moreover he was uncle to Priam, and how Priam could be related to a prince in Africa it seems difficult to imagine. If he were an Asiatic prince, located somewhere near Susa, in the old Scriptural Cush or Ethiopia, then we could understand his relationship to a prince of the Troad, and his advent, with 2,000 dusky warriors to help his relative against the Occidentals. Moreover, M. De Quatrefages and Dr. Hamy, affirm that negroid tribes still exist between the Tigris and Euphrates, and if this be the case, we see at once the existence of Asiatic Ethiopians clearly demonstrated. $\dagger$

Dr. Pickering points out some remarkable coincidences between Fijian and Eastern African customs, such as the use of the neck-pillow, circumcision, similar modes of dressing the hair, even to the staining of it to a flaxen hue, $f$ and they may thus be logically accounted for, without recourse to Professor Seeley's somewhat far-fetched hypothesis.

The only other mention of Papuan or Negritto races in Asia, of which I am aware, is the statement of Herodotus that the inhabitants of Colchis, near the Black Sea, resembled Egyptians by their dark colour and frizzled hair. Very possibly in that congeries of disintegrated races-that ethnological ark-the Caucasus, some remnants of the primitive Papuan aborigines of Asia may long have lingered. $§$

* See an essay upon "La Statue Vocale de Memnon," in "Aquarelles Africaines," by Emile Guimet. Paris, J. Hetzel \& Co.

† See "Crania Ethnica," and "Revue d'Anthropologie," published in Paris.

I " Races of Men," p. 174.

$\S$ “ For the Colchians were evidently Egyptians, and I say this having myself observed it before $I$ heard it from others; and as it was a matter of interest to me I inquired of both people, and the Colchians had more recollection of the Egyptians than the Egyptians of the Colchians; yet the Egyptians said they thought the Colchians were descended from the Army of Sesostris; and $I$ formed my conjecture, not only because they are swarthy and curly-headed, for this amounts to nothing, because others are so likewise, but chiefly from the tollowing circumstances : because the Colchians, Egyptians, and Ethiopians, are the only nation of the world who, from the first, have practised circumcision," \&c., (Euterpe, Book II, Section 104, Cary's translation.) . . . "I will now mention another fact respecting the Colchians, how they resemble the Egyptians. They alone and the Egyptians manufacture linen in the same manner; and the whole way of living, and the language, are similar in both nations," \&c. (Ibid., Sec. 115.) 
Quitting the consideration of the extreme westward extension of the Papuan and Negritto races, we will now take a view of the extension of these races in the direction of America.

In the first place, although the fact seems to be little known, there exist plain proofs in the traditions of the Maories or Malay Polynesian inhabitants of New Zealand that these islands once lay within the Papuan area, and that the real aborigines were exterminated, within comparatively recent times, by the ancestors of the present New Zealanders.

The veteran missionary, the Rev. Mr. Taylor, tells us* that the native records of the Maori arrival by sea distinctly bear witness that the immigrants fought with, and overcame "the men of the island" a black race whom they nicknamed by a native term meaning "Naked sides," because they wore so little clothing, and also denominated "Black Fellows." It would be well if osteologists and comparative anatomists would carefully examine all human bones found in the islands, with a view to ascertaining whether two types of skull are discoverable in the old burial places, and if either of these resembles the Papuan or Negritto types.

Meanwhile, there is little doubt that in the isolated and apparently Negritto race found in the Chatham Islands, about 400 miles due east of the Canterbury Settlement in the Middle Island, we have a precisely similar race to the former black inhabitants of New Zealand. These islands were only discovered in 1791, yet the aggressive tendency of the Malay Polynesians is shown by the fact that a Maori tribe somewhere about 1820, chartered a European vessel, and speedily effected a conquest of the islands. $\dagger$-Now, missions from Germany and New Zealand work there, and it would be interesting to receive fuller accounts of the aboriginal race. They appear to be very degraded, and their canoes are merely wicker-work, tied together by cordage of indigenous flax, there being no timber in the islands.

It is a tempting subject for speculation, whether the Papuans ever succeeded in reaching America from their Polynesian and Melanesian homes. Although traditions, I believe, exist in some of the islands of Eastern Polynesia as to the former existence of black tribes there, no Papuans or Negrittos are at present found far to the eastward of the Fiji Islands, and of Chatham Island.

The tendency indeed appears to have been for a long time to restrict the Papuan area, since, when we took over the sovereignty of Fiji, the wily Malay Polynesian Tongan chief Maafu, the

* In his work on "New Zealand and its Inhabitants."

† See article "Chatham Islands" in "Penny Cyclopædia." 
representative of a Tongan colony settled in Fiji by King George of the Friendly Islands, had very nearly succeeded by judiciously interfering in the native quarrels in supplanting the Papuan Thakombau in the suzerainty of Fiji.

Williams, the missionary, observes that "the latter [Malays] being a fierce and treacherous people succeeded in extirpating them [the Papuans] from the smaller islands and groups,"** and Earl adds that although certainly not inferior in mental capacity to the brown tribes, "their impatience of control while in an independent state utterly precludes that organization which would enable them [the Papuans] to stand their ground against encroachment; and they invariably fall under the influence of the Malayans whenever the two races are brought into contact." $\dagger$

This curious mental deficiency seems to prove that the Papuans are the original race and the Malays the interlopers, a theory which the fact of the Malay traditions always recording an arrival by sea, appears to confirm.

At the same time, it is by no means impossible that at some remote epoch, before the advent of the Malay-Polynesians, the Papuans and Negrittos were the great colonizing race in this part of the world ; for the Fijian canoes were superior to those of all the other races, and were good sea-going boats, $\$$ and even the barbarous Andamaners or Mincopies have good outrigged canoes.

It seems, therefore, not unlikely that in remote ages small parties of Papuans may have succeeded in reaching America. Dr. Pickering thinks that stories of black aborigines in America may be all referred to successive arrivals of Malay Polynesians ; but Papuans would surely answer more closely to the appellation black?

Sir Arthur Helps tells us, in his " History of Spanish Conquest in America" that the Spaniards, when they first visited Darien under Vasco Nuñez, found there a race of black men, whom they (gratuitously, as it seems to me) supposed to be descended from a cargo of shipwrecked negroes; this race was living distinct from the other races and at emnity with them. I Some of these blacks built for themselves houses in trees, just as the Papuans often do.** These people allied themselves with the

* See "Missionary Enterprises," p. 513.

† See "The Papuans," p. 6.

士 "Races of Men," p. 115. (See also the map in front.)

$\S$ According to Mr. Pritchard, late Consul there : Dr. Pickering thinks differently.

|| See Mr. W. L. Ranken's Paper on the "South Sea Islanders," Journ. Anthrop. Vol. VI, p. 223.

of See Vol. I, p. 360.

** Ibid., Vol. I, p. 421 . 
Spaniards in their contests with the Indians. It is a great pity that no further details or words of their language have been preserved, for I have little doubt that we have here a trace of a primitive Papuan colony in America. The slave trade with Africa had hardly commenced by this time, and the supposition that they were African negroes seems very unfounded.

Perhaps other black tribes may be discovered upon a more careful inquiry, and, if the theory of Crawford be accepted, which represents the inhabitants of Polynesia in ante-historic times as being a great semi-civilized nation who had made some progress in agriculture and understood the use of gold and iron, were clothed "with a fabric made of the fibrous bark of plants, which they wove in the loom," and had several domesticated animals, a new and unexpected light may possibly be thrown upon the origin of primitive American culture. It is certain that massive ruins and remains of pyramidal structures and terraced buildings closely analogous to those of India, Java, and Cambodia, as well as to those of Central America, Mexico, and Peru, exist in many islands of Polynesia, such as the Ladrone Islands, Tahiti, Fiji, Easter Island, and the Sandwich Islands, and the customs of the Polynesians are almost all of them found to exist also amongst the American races.

Wallace says repeatedly that the Papuan has a higher intellectual capacity and "feeling for art" than the Malay, * and Dr. Pickering calls the "Fijians a far more ingenious people than the (Malay) Polynesians." $\dagger$

Farl says that "the Papuans are beyond all comparison superior in vigour, both mental and physical, to those tribes of the brown race with whom they are brought in contact." $\ddagger$

Perhaps here, then, we have "the missing link" between the old World civilizations and the mysterious civilizations of America. At any rate, I hope that you will pardon me for having called attention to certain facts in connection with the distribution of the Papuan race which I thought in danger of being overlooked. The black races of Asia, Polynesia, and America are evidently worthy of particular study.

\section{Discussion.}

Mr. Hyde Clarke said: A distinction must be drawn between the short black Negritto races and the tall blacks or Negroes. A line of dwarfs reached across Africa from the Akkas or Pygmies in the north-east to the Obongo and to the Gulf of Guinea. All these

* See " Malay Archipelago," p. 587.

† See Pickering's " Races of Men," pp. 152-3.

† See "Papuans," p. 68. 
spoke allied languages. Language was to be required as a proof of association rather than as a test of race. Then there was the curious circumstance that in the Tasmanian languages were traces of the Nyam-Nyam of the African Lake regions. In America there were short dark races north and south, and their languages presented peculiar features. With regard to the connection between India and Africa, he had prepared for the Royal Asiatic Society, a paper showing the connection with Africa of the Bodoxe, of the Naga, and of the Kolarian. It did not appear as if a geological bridge were needed to connect India and Africa. As to what Mr. Allen had said about blacks in Central America, he would call attention to his own paper in the Journal, showing the connection with Africa of the language and mythology of the Bribris of Central America. Also as to the passage in Herodotus about the Colchians, this he had dealt with in the paper on the connection of the Ude language of the Cancasus with the Egyptian and Coptic. This had been confirmed by the discovery on coins at Axum in Ethiopia with names corresponding to those of Caucasian kings. The fact cited from Herodotus by $\mathrm{Mr}$. Allen as to the Eastern Ethiopians, was a valuable suggestion for the history of the early extension of the black races in the Nortk.

Mr. MogGRIDGe said: I would beg, sir, to return my thanks to the author of the paper we have just heard, the result evidently of much research. On one point, however, I must differ from him; he would consider the Negrittos to be a branch of the Papuans; now there are not only marked differences in language, stature, and frame, bat also in the skulls of those two races, which I have recently had an opportunity of comparing.

Colonel Godwin Austen said : Mr. Allen has referred to the rockcut temples of the Bombay Presidency. I am of opinion that a connection has long existed between Africa and that part of India. When visiting the Cave of Elephanta, I was particularly struck by the similarity of the sculptures to old Egyptian in the protruding lips and the mode in which the hair is depicted. In making this remark, I do not wish it to be understood that it has any relation to the question of such peoples as the Andamanese having an African origin. They may quite as likely be the remnants of a very early Asiatic race and spread westward.

Mr. ALLEN in reply, stated that he had himself only been able to discover meagre references to the former existences of black races in America; but had thought it best in the interests of science to bring these forward, as further research might throw light upon the subject. He could not venture to express an opinion as to whether the Negrittos were simply Papuans living under unfavourable circumstances, or a different and earlier although allied and cognate race. He had the anthority of Mr. Earl in his work on The Papuans for the former opinion, and also for the assertion that some tribes of Australians in the north and north-east had woolly and frizzled hair (p. 189.) He had not used or placed any credence in recent mythical Travels in New Guinea, as a gentleman 
had suggested. Much remained yet to be discovered about the Papuans and Negrittos, and he was anxious to stimulate research regarding them.

Major-General Lane Fox, Mr. Bonwick, Mr. Bouverie Pusey, the Rev. Edgell Wyatt Edgell, and the President, offered some remarks.

The Director read a Paper from Dr. Julius Von. HAast on " Rock Paintings in New Zealand."

Notes on some Ancient Rock Paintings in New Zealand. By Julius von HaAst, Ph.D., F.R.S., Director of the Canterbury Museum and Professor of Geology in Canterbury College (New Zealand University), Christchurch.

ThE history of the races inhabiting the Pacific Ocean is so obscure and the theories concerning their migrations are so contradictory that any new discovery which might throw light upon these interesting subjects will doubtless be of considerable value to the scientific world. I have therefore thought that a copy of some remarkable rock-paintings lately discovered in New Zealand, made with the greatest care by Mr. T. S. Cousins on a scale of one inch to the foot, together with my views on the subject, might be acceptable to your Society.

I have no doubt that these rock-paintings when closely examined by archæologists and linguists will throw some light upon the questions at issue and at least prove that at one time there has been some immigration to New Zealand, either voluntary or accidental, from the north-west and from countries which then possessed a far higher civilization than the Maories ever reached.

Although I looked carefully over all the traditions of the former history of the New Zealanders there is not the least trace of such immigration being recorded.

About a year ago Mr. Alexander Lean informed me of the existence of these paintings, which are situated on an educational reserve about one mile on the western side of the Weka Pass road, not far from the last rise from which that picturesque road descends into the Waikari Flat. Shortly afterwards I visited them and I need scarcely observe that I was very much struck with their peculiar character and their state of partial preservation, from which their great age could be inferred.

The so-called case which is, however, only a rock shelter, is washed out of a vertical wall of rock lining a small valley for 